\title{
Earthquakes in India and the Himalaya: tectonics, geodesy and history
}

\author{
Roger Bilham \\ Cooperative Institute for Research in Environmental Sciences (CIRES) and Geological Sciences, \\ University of Colorado, Boulder, CO, U.S.A.
}

\begin{abstract}
The record of earthquakes in India is patchy prior to 1800 and its improvement is much impeded by its dispersal in a dozen local languages, and several colonial archives. Although geological studies will necessarily complement the historical record, only two earthquakes of the dozens of known historical events have resulted in surface ruptures, and it is likely that geological data in the form of liquefaction features will be needed to extend the historical record beyond the most recent few centuries. Damage from large Himalayan earthquakes recorded in Tibet and in Northern India suggests that earthquakes may attain $M=8.2$. Seismic gaps along two-thirds of the Himalaya that have developed in the past five centuries, when combined with geodetic convergence rates of approximately $1.8 \mathrm{~m} / \mathrm{cy}$, suggests that one or more $M=8$ earthquakes may be overdue. The mechanisms of recent earthquakes in Peninsular India are consistent with stresses induced in the Indian plate flexed by its collision with Tibet. A region of abnormally high seismicity in western India appears to be caused by local convergence across the Rann of Kachchh and possibly other rift zones of India. Since the plate itself deforms little, this deformation may be related to incipient plate fragmentation in Sindh or over a larger region of NW India.
\end{abstract}

Key words India - earthquakes - history

\section{Introduction}

Throughout the invasions of different ethnic and religious entitites in the past two millennia the Indian subcontinent has been known as Hindoostan, Hindustan or India in recognition of its unique isolation imposed by surrounding mountains and oceans. The northern, eastern and western mountains are the boundaries of the Indian plate. The shorelines are the echoes of ancient plate boundaries. Only in recent time have the separate nations of Pakistan, India, and Bangladesh subdivided the continental expression of the Indian Plate. In this

Mailing address: Dr. Roger Bilham, Cooperative Institute for Research in Environmental Sciences (CIRES) and Geological Sciences, University of Colorado, Boulder, CO 80309-0399, U.S.A.; e-mail:Roger.Bilham@colorado.edu article I shall use the term India to signify both the Indian tectonic plate and the subcontinent of India.

Perhaps the most disappointing observation is that despite a written tradition extending beyond 1500 B.C. we know very little about Indian earthquakes earlier than 500 years before the present, and records are close to complete only for earthquakes in the most recent 200 years. This presents a problem for estimating recurrence intervals between significant earthquakes, the holy grail of historic earthquake studies. Certainly no repetition of an earthquake has ever been recognized in the written record of India and the Himalaya, although great earthquakes in the $\mathrm{Hi}^{-}$ malaya should do so at least once and possibly as much as three times each millennium. The strain rate within the Indian plate is observed to be less than 3 ns/yr (Bilham and Gaur, 2000) and the renewal time for earthquakes in the sub-continent may exceed many thousands of years, rendering it unlikely that earthquakes will have repeated during the time of written records. 
In contrast, trench investigations indicate that faults have been repeatedly active both on the subcontinent (Sukhija et al., 1999; Rajendran, 2000) and within the Himalayan plate boundary (Wesnousky et al., 1999). The excavation of active faults and liquefaction features is likely to play an important role in extending the historical earthquake record of Indian earthquakes in the next several decades.

A feature of Indian earthquakes for which numerical deformation data have recently been exhumed is that these data, once analyzed, have required substantial revision of earlier informed, but speculative, interpretations of the causal mechanisms of historic earthquakes. Geodetic data have surfaced for the 1819, 1881, 1897 and 1905 earthquakes that have largely negated the conclusions of many learned articles. This obviously raises a cautionary flag: that conclusions concerning felt reports about earthquakes in history and prehistory have limited value in interpreting subsurface structure.

I first give a brief overview of Indian tectonics. I then describe catalogues and data that characterize Indian earthquakes, and conclude with a number of case histories that discuss some of the important problems that have surfaced in studies of Indian earthquakes, and that may be resolved by the discovery of further data. I conclude with a discussion of our current understanding of seismic hazard in India and the Himalaya.

\section{Tectonic setting of India}

India is currently penetrating into Asia at a rate of approximately $45 \mathrm{~mm} / \mathrm{yr}$ and rotating slowly anticlockwise (Sella et al., 2002). This rotation and translation results in left-lateral transform slip in Baluchistan at approximately 42 $\mathrm{mm} / \mathrm{yr}$ and right-lateral slip relative to Asia in the Indo-Burman ranges at $55 \mathrm{~mm} / \mathrm{yr}$ (fig. 1). Because of complexities in the structural units at its northern, western and eastern boundaries these velocities are not directly observable across any single fault system. Deformation within Asia reduces India's convergence with Tibet to approximately 18 mm/yr (Wang et al., 2001), and because Tibet is extending east-west, convergence across the Himalaya is approximately normal to the arc. Arc-normal convergence across the Himalaya results in the development of potential slip available to drive large thrust earthquakes beneath the Himalaya at roughly $1.8 \mathrm{~m} / \mathrm{cy}$, hence earthquakes associated with, say, $6 \mathrm{~m}$ of slip cannot occur before the elapse of an interval of at least three centuries (Bilham et al., 1997).

Slip across the $150-300 \mathrm{~km}$ wide plate boundary between Asia and India in Baluchistan is apparently partitioned between thrust and strike-slip components. For example, the 1931 Mach $M_{s}=7.3$ earthquake was associated with 1 $\mathrm{m}$ of NW directed reverse slip on a fault that may have extended entirely through the crust. It was followed 4 years later by the $M_{s}=7.7$ strike-slip Quetta earthquake on a subparallel fault less than $150 \mathrm{~km}$ NW of the Mach event. The Mach event slipped in a sense that effectively unclamped the subsequent Quetta earthquake (Ambraseys and Bilham, 2003a). Slip on the Chaman fault further to the north in Afghanistan in the past century, and possibly for a longer period, has been much less than $42 \mathrm{~mm} / \mathrm{yr}$ according to seismic moment summation of observed seismicity (Ambraseys and Bilham, 2003b). Although this may be the result of minor deformation in the northern Afghan mountains, or unreported creep on the Chaman fault, it is quite possible that the northern Chaman fault system may be overdue for a large earthquake.

Slip in the IndoBurman ranges is also accompanied by strike-slip and thrust seismicity and although no recent large earthquakes have occurred on land, the north-south Sagaing fault system is clearly strike-slip and the Indo-Burman ranges to its west the result of distributed east-west convergence. Near the Andaman Islands slip is partitioned between thrust earthquakes to the west and beneath islands, and strike-slip faulting on the North Andaman fault to their east (Curray et al. 1979; 1982; Ortiz and Bilham, 2003)

GPS measurements in India reveal that convergence is less than $5 \pm 3 \mathrm{~mm} / \mathrm{yr}$ from Cape Comorin (Kanya Comori) to the plains south of the Himalaya (Paul et al., 2001). Hence the Indian Plate should not be expected to host frequent seismicity. However, the collision of India has resulted in flexure of the Indian Plate (Bilham et al., 2003). The wavelength of this flexure is of the order of $650 \mathrm{~km}$ and results in an approximately 450 -m-high bulge near the central 


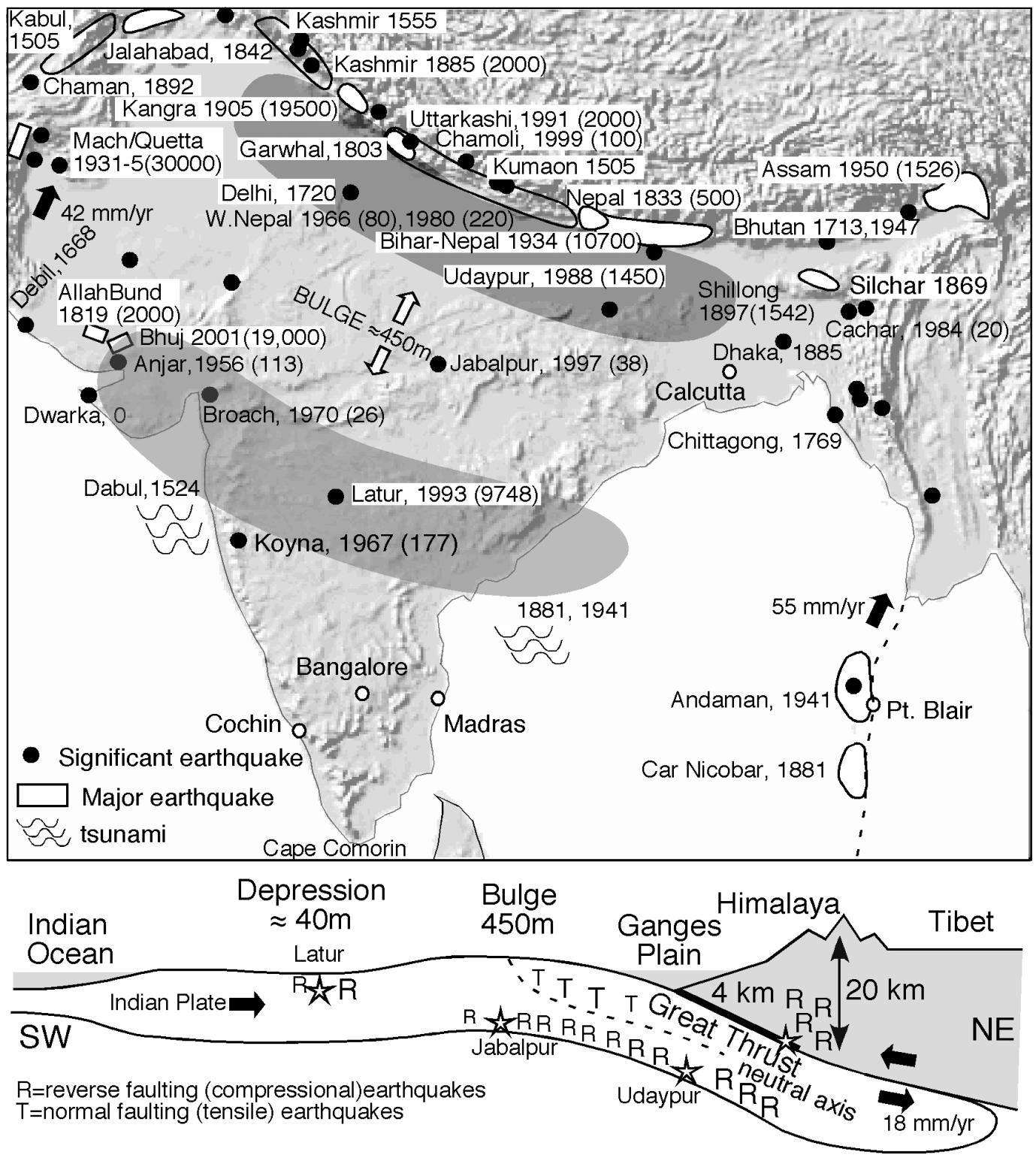

Fig. 1. Schematic views of Indian tectonics. Plate boundary velocities are indicated in $\mathrm{mm} / \mathrm{yr}$. Shading indicates flexure of India: a $4 \mathrm{~km}$ deep trough near the Himalaya and an inferred minor $(40 \mathrm{~m})$ trough in south central India are separated by a bulge that rises approximately $450 \mathrm{~m}$. Tibet is not a tectonic plate: it extends eastwest and converges north-south at approximately $12 \mathrm{~mm} / \mathrm{yr}$. At the crest of the flexural bulge the surface of the Indian plate is in tension and its base is in compression. Locations and dates of important earthquakes mentioned in the text are shown, with numbers of fatalities in parenthesis where known. With the exception of the Car Nicobar 1881, Assam 1897 and Bhuj 2001 events, none of the rupture zones of major earthquakes are known with any certainty. The estimated rupture zones of pre-1800 great earthquakes are shown as unfilled outlines, whereas more recent events are filled white. 
Indian Plateau, corresponding to the outer rise of an oceanic collision. Normal faulting earthquakes occur north of the flexural bulge (e.g., possibly on 15 July 1720 near Delhi) and deep reverse faulting occurs beneath its crest (e.g., the $M=6.321$ May 1997 Jabalpur earthquake). Shallow reverse faulting occurs south of the flexural bulge where the Indian plate is depressed (e.g., the $M=6.329$ September 1993 Latur earthquake, fig. 1).

The Indian plate is bent downwards by 4-6 $\mathrm{km}$ beneath the southern edge of the Himalaya attaining depths of $18-20 \mathrm{~km}$ beneath the southern edge of Tibet (fig. 1). Stresses within the plate vary from tensile above the flexed neutralaxis to compressional below it. Where no inplane end-loading prevails the position of the neutral axis lies theoretically half way through the thickness of the elastic plate. Since in-plane stresses of the order of 500 bars exist (necessary to maintain the height of the Tibetan Plateau) this effectively means that the neutral axis rises above the plate south of the crest of the central Indian bulge. The neutral axis descends into the plate just north of the bulge where it is initially flexed downward. The axis would descend to a path a little above half-way through the plate were it perfectly elastic, since the flexural stresses are much larger than the weak in-plane collisional stresses. However, normal-faulting in the upper surface of the plate near the Ganges Trough weakens the top surface of the plate thereby lowering the neutral axis, and plastic conditions near the base of the plate both raise the neutral axis, both thinning the effective elastic thickness and shifting the neutral axis to an unknown depth. Eventually, when sufficient focal mechanisms are available from the descending plate, it may be possible to identify the location of the neutral axis from the absence of earthquakes near the axis, and from the difference in mechanisms above and below it.

The presence of both flexural stresses and plate-boundary slip permits all mechanisms of earthquakes to occur beneath the Lesser Himalaya (fig. 1). At depths of $4-18 \mathrm{~km}$ great thrust earthquakes with shallow northerly dip occur infrequently that permit the northward descent of the Indian plate beneath the subcontinent. Earthquakes in the Indian plate beneath these thrust events range from tensile just below the plate interface, to compressional and strikeslip at depths of 30-50 km (e.g., $M=6.620 \mathrm{Au}-$ gust 1988, Udaypur).

A belt of microearthquakes and moderate earthquakes beneath the Greater Himalaya on the southern edge of Tibet indicates a transition from stick-slip faulting to probable aseismic creep at around $18 \mathrm{~km}$. This belt of microseismicity defines a small circle with radius 1695 km (Seeber and Gornitz, 1983; Bendick and Bilham, 2001). Seismicity in Tibet is largely shallow and is either normal faulting or strike-slip faulting.

The flexural geometry of the Indian plate is manifest as a standing wave fixed relative to southern Tibet. Stresses in the plate vary with time because the Indian plate streams slowly though this flexural wave, bringing points within India towards, or away from, compressional or tensile failure. It is for this reason that the earthquakes that occur throughout central and northern India appear to have no distinctive spatial pattern. The flexural stresses are significantly larger than the in-plane stresses needed to sustain the elevation of the Tibetan Plateau, but their change with time is slow (mbar/yr). Despite this their spatial change is large (up to 2 bars per km northeastward) and this results in an important imposed south-north spatial variation in stress (Bilham et al., 2003). Stress changes of less than 1 bar are known to trigger earthquakes. Although stresses throughout most of NE India are everywhere close to failure, the triggering of earthquakes occurs partly from the movement of India through the flexural stress field, and partly from local stress perturbations caused by other tectonic, erosional or dynamic processes.

\section{Historical data sources and catalogues}

Early earthquakes described in mythical terms include extracts in the Mahabharata $(\approx 1500$ B.C. $)$ during the Kurukshetra battle (Iyengar, 1994), and several semi-religious texts that mention a probable Himalayan earthquake reputed to have occurred during the time of enlightment of Buddha ca. 538 B.C. 


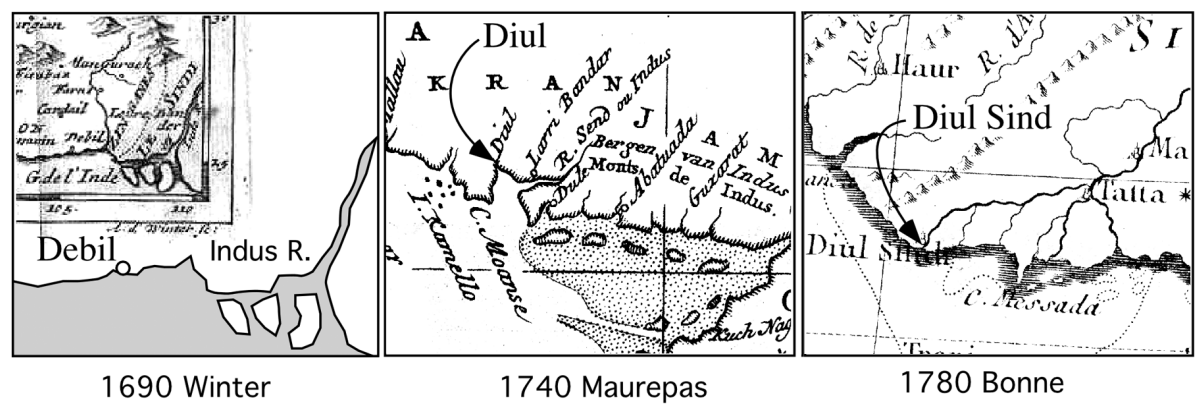

Fig. 2. Maps in 1690 and 1740 show Debil near the current location of Karachi. Other maps show it on a distributary of the Indus. An earthquake occurred there in 1668 and another is alleged by Thomas Oldham (1883) to have occurred in 893 but the event he invokes occurred in an Armenian town with a similar name (Ambraseys, 2004). The city is last mentioned in the 18th century (Yule et al., 1903)

Archeological excavations in Sindh and Gujarat suggest earthquake damage to now abandoned Harrappan cities. A probable earthquake around 0 A.D. near the historically important city of Dwarka is recorded as a zone of liquefaction in archeological excavations of the ancient city (Rajendran et al., 2003). The town of Debal (Dewal, Debil, Diul Sind or Sindi) near the current site of Karachi was alleged to have been destroyed in 893 A.D. (Oldham, 1883), but until recently accounts of its collapse and inundation were considered too vague to be taken seriously. Rajendran and Rajendran (2002) present a case that the destruction of Debil was caused by an earthquake linked to the same fault system responsible for the 1819 and 2001 Rann of Kachchh earthquakes, however, Ambraseys (2003) notes that Oldham's sources refer to Daibul (Dvin) in Armenia, and that liquefaction 1100 years ago in western India must be attributed to a different earthquake. Figure 2 shows the location of Debil west of the Indus delta in a 1690 map drafted by A.D. Winter. Other maps place it within the distributaries of the Indus. Yule and Burnell (1903) describe Debil's 1000-year-long history, prior to its effective disappearance from accounts within a century of a second earthquake in its vicinity in 1668 (Oldham, 1883; Ambraseys, 2004).

A single paragraph describes a massive earthquake in the Kathmandu Valley in 1255 (Wright, 1877), which may have been a great earthquake because it is alleged to have been followed by three years of aftershocks, but the absence of reports from other locations renders this of little value in estimating its rupture dimensions or magnitude. Similarly the arrival of Vasco de Gama's fleet in 1524 coincided with a violent sea-quake and tsunami that caused alarm at Dabul (Bendick and Bilham, 1999). Note that this Portuguese port at latitude $17^{\circ} 34^{\prime}$ on the Malabar Coast is unrelated to Debil above. This could have been a local event, but since it was not reported onshore it could have been the tsunami from a remote earthquake that occurred along the Makran or Gujarat coastlines. Such accounts are thus of fragmentary value in quantifying earthquake locations and sizes.

The emergence and disappearance of coastal tracts has sometimes been ascribed to earthquakes. A storm near Cochin in 1341 caused an island to emerge, but inspection suggests this to be a common accretional feature of storms along the Malabar Coast (Bendick and Bilham, 1999). An island that sank in 1769 south of Chittagong (Oldham, 1883) may have undergone lateral spreading at the time of significant earthquake near there (Seeber, pers. comm., 2003).

In the mid 19th century some of these fragmentary data were collected successively in summaries of earthquakes by Mallett, BairdSmith and Oldham, but there followed more than a century of archival neglect when little 
new information surfaced. The seismicity of the sub-continent has been summarized in compilations by Chandra (1977), Srivastava and Ramachandram, (1985), Rao and Rao (1984) and by Khattri (1987). Recent interest in early earthquakes have engaged historians in India and elsewhere in a systematic search through Urdu, Arabic, Tibetan, Chinese, Nepalese and European languages.

Two important publications summarize recent findings: Iyengar and Sharma (1998) report accounts in Arabic, Sanskrit and Urdu sources and Ambraseys and Jackson (2003) provide new data from Tibet and recently collated colonial records. Data presented in these publications remain sparse but provide a skeletal framework of events on which to build a future quantitative assessment of historic Indian earthquakes as new documents surface.

A list of Indian earthquakes is to be found in Bapat et al. (1983) but this contains numerous entries that have been included uncritically from secondary sources, and for these reasons can be misleading. Similarly, entries in the uncritical listing of Dunbar et al. (1992) require careful evaluation before use. A useful and easily accessible compilation of information and resources for the study of Indian earthquakes is a webpage maintained by Stacey Martin, http://asc-india.org/menu/gquakes.htm. Relocated instrumental earthquakes are listed by Engdhal et al. (1998).

An important recent realization is that a sequence of significant earthquakes occurred throughout the west Himalaya in the 16th century. The sequence started in Kashmir in 1501, followed by two events a month apart in Afghanistan and the central Himalaya, concluding with a large earthquake in Kashmir in 1555. The central Himalayan 1505 earthquake may have been $M_{w} \geq 8.2$ based on its probable rupture area. It destroyed monasteries along a 500 $\mathrm{km}$ segment of southern Tibet, in addition to demolishing structures in Agra and other towns in northern India (Jackson, 2002; Ambraseys and Jackson, 2003; Bilham and Ambraseys, 2004).

A Himalayan earthquake that damaged the Kathmandu Valley in 1668 is mentioned briefly (a single sentence) in Nepalese histories but as with events in 1255 and 1408 no details are giv- en (Chitrakar and Pandey, 1986). Earthquakes in the 18th century are poorly documented. An earthquake near Delhi in 1720 caused damage and apparent liquefaction but little else is known of this event (Kahn, 1874; Oldham, 1883). This event, from its location, could have been a normal faulting event, but because of the absence of damage accounts from the $\mathrm{Hi}$ malaya it may have been a Himalayan earthquake. In 1713 a severe earthquake damaged Bhutan and parts of Assam (Ambraseys and Jackson, 2003).

Thirteen years later, in September 1737, a catastrophic earthquake is alleged to have occurred in Calcutta. This is the most devastating earthquake to be listed in many catalogues of Indian (and global) earthquakes but is actually a storm surge that resulted in numerous deaths by drowning along the northern coast of the Bay of Bengal. The handwritten ledgers of the East India Company in Bengal detail storm and flood damage to shipping, wharves, warehouses and dwellings in Calcutta with an estimate of 3000 deaths by drowning (Bilham, 1994). Calcutta's population at the time was approximately 30000 . A figure of 300000 fatalities is often ascribed to this «fake quake» for which earthquake shaking was probably invoked in news reports as a metaphor for destruction, a possible description of the buffeting accompanying extreme wind velocities. The spire of St. Annes church, Calcutta, was blown down by these winds, but the masonry church survived. An approximate $10 \%$ increase in burials is recorded in its churchyard for 1737, an increase in deaths that year by fewer than two dozen. Although the death-toll from drowning along the coast of southern Bengal was presumably greater than the official estimates in Calcutta, the fatality count of 300000 is repeated only in accounts published in monthly magazines and newspapers in Europe, and is not substantiated by official documents from any of the several administrative centers then functioning in Bengal.

India in the early 19th century was as yet incompletely dominated by a British colonial administration. Remote administrators in distant parts of the India subscribed to newspapers and wrote verbose and sometimes extensive descriptions of their experiences which were typ- 
ically printed and circulated to each administrative outpost. An earthquake in India was something of a rarity and generated detailed letters from residents describing its effects. Very often the same report would be copied verbatim from one newspaper and reported by another. Few of the original letters have survived, but the earthquakes in Kumaon in 1803, Nepal in 1833 and Afghanistan in 1842 were felt sufficiently widely to lead scientifically inclined officials to take a special interest in the physics and geography of earthquakes. Mallett's (1853-1855) global catalogues of earthquakes included several from India, with a special section devoted to the 1833 earthquake for which he discussed seismic propagation velocities.

At about the time of the sequential publication of Mallet's global catalogue an army officer named Baird-Smith wrote a sequence of articles (1843a,b,1844) in the Asiatic Society of Bengal summarizing data from several Indian earthquakes and venturing to offer explanations for their occurrence. He was writing shortly after the first Afghan war which had coincided with a major 1842 earthquake in the Kunar Valley of NE Afghanistan (Ambraseys and Bilham, 2003b), which must have impressed him and others in the military service who were in NW India at the time. Baird-Smith's accounts of other earthquakes include citations from his sources.

The director of the Geological Survey of India, Thomas Oldham (1816-1878) published the first real catalog of significant Indian events in 1883. His catalog includes earthquakes from 893 to 1869 , and acknowledges the works of Mallet and Baird-Smith. His important additions include verbatim textual extracts with references that permit verification and further work. His notes on some of the earthquakes form the first detailed studies of individual earthquakes in India.

His son, Richard. D. Oldham (1858-1936), wrote accounts of four major Indian earthquakes (1819, 1869, 1881 and 1897). He completed first his father's manuscript on the 1869 Silchar, Cachar, Assam earthquake which was published under his father's name (Oldham, 1884). He next investigated the $M_{w}=7.9$ December 1881 earthquake in the Andaman Islands, visiting and mapping the geology of some of the islands (Oldham, 1884, 1885). He mistakenly located the event deep in the northern Bay of Bengal based largely on timing data from clocks in Calcutta and Madras. An analysis of the tsunami generat-
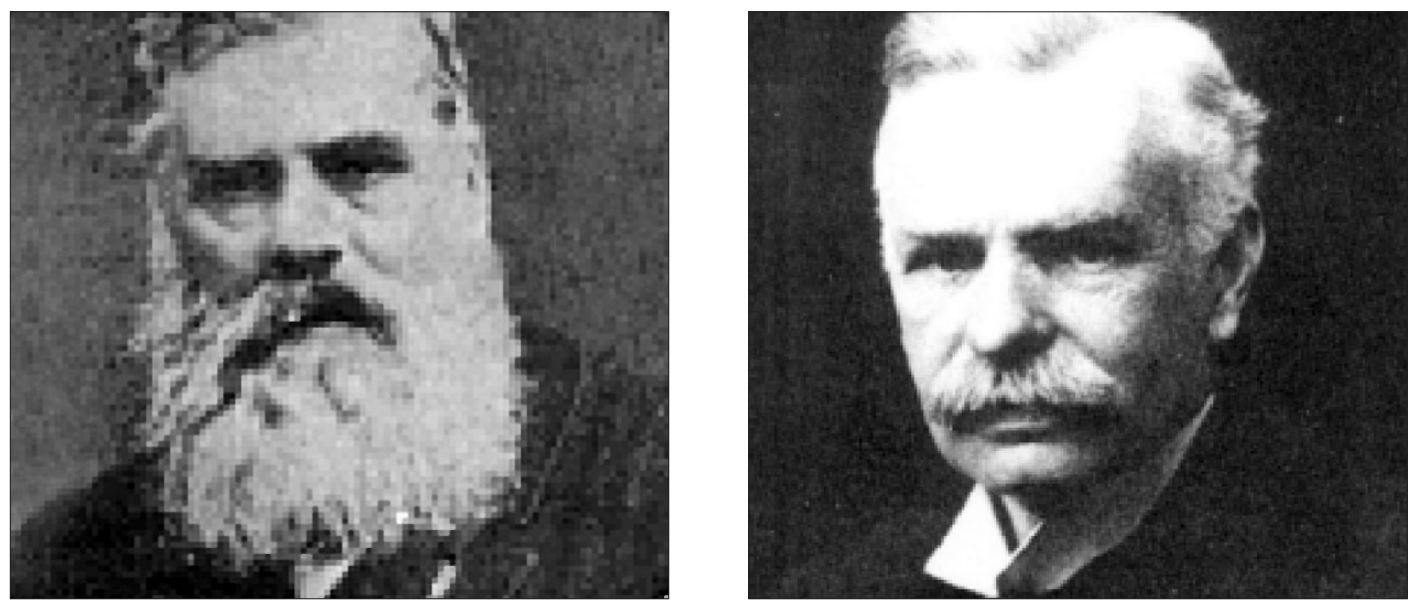

Fig. 3. Oldham, father and son, were both geologists in India. Thomas Oldham (left) compiled the first catalogue of Indian earthquakes. Richard (right) made definitive studies of individual earthquakes $(1819,1869,1881$ and 1897) in addition to identifying for the first time $p$-waves and $s$-waves, and the core of the earth. 
ed by this earthquake places it on the subduction zone west of Car Nicobar (Ortiz and Bilham, 2003). His account of the $1897 M_{w}=8.1$ Shillong Plateau earthquake in Assam (Oldham, 1899) was exemplary, and according to Richter provided the best available scientific analyses of available physical data on any earthquake at the time. In contrast to the care with which he investigated the geological, geodetic and geophysical aspects of the earthquake, Oldham's reports are thin on specific accounts of building damage which he felt were often exaggerated. Despite the care with which he interpreted the intensity data available to him, his estimated intensities for the 1897 earthquake on a modified version of the Rossi-Forel scale are 1.5 to 3 intensity units too high in the epicentral region (Ambraseys and Bilham, 2003c).

R.D. Oldham's accounts established a template for the study of earthquakes that occurred in India subsequently. The great earthquakes of 1905 Kangra (Middlemiss, 1910) and 1934 Bihar/Nepal (Dunn et al., 1939) were each assigned to Geological Survey of India special volumes, but these never quite matched the insightful observations of Oldham's 1899 volume. Investigations of the yet larger Assam earthquake of 1950 were published as a compilation undertaken by separate investigators (e.g., Poddar, 1953; Ray, 1953; Tandon, 1953). In many ways this proved to be the least conclusive of the studies of the 5 largest Indian earthquakes 18191950. Information available to Indian authors on the effects of the earthquake were confined largely to a narrow corridor of information along the Brahmaputra valley since access to Tibet, Burma, or the tribal regions south of the epicenter was unavailable. Regrettably geologists did not make a thorough search for surface faulting in the epicentral region and geodesy near the epicenter was virtually non-existent.

\section{Uncertainties associated with the 6 June 1819 Allah Bund earthquake}

Oldham wrote his account of the 1819 earthquake in Kachchh in retirement in England (Oldham, 1928). His monograph synthesized all the data available for the Allah Bund earth- quake on the northern edge of the Rann of Kachchh close to what is now the India/Pakistan border. The earthquake figures prominantly in Lyell's Principles of Geology (1830) as one of the first clear examples of geological uplift associated with an earthquake.

Oldham's 1928 account refers to, but does not reproduce, Baker's map and profile from a leveling survey crossing the Allah Bund. This profile is key to quantifying the mechanism of the earthquake, and it is entirely due to its serendipitous discovery by Oldham (1898) that we have access to it. The map had been accidently omitted in Baker's original 1846 publication by the editor. In a frontispiece to the $\mathrm{Ge}$ ographical Society of Bombay in 1846 he apologizes for omitting the map and cross-section and promises to include the figure in subsequent issues, a promise that he failed to fulfill. Oldham had discovered the map quite by accident when supervising a clean-up of the Bombay office of the Survey of India. In his discussion of the cause of the 1819 Allah Bund earthquake Oldham speculates that the morphology across the natural dam measured by Baker in 1846 was caused by subsurface faulting akin to that reported from Japanese earthquakes in the early 20 th century.

Assuming the surface morphology to be representative of co-seismic deformation during a single earthquake, Baker's $6 \mathrm{~m}$ crest-totrough observation is consistent with $11 \mathrm{~m}$ of slip on a north-dipping reverse fault terminating 0.5-2 km below the surface (Bilham, 1999). However, recent geological studies in the region (Rajendran and Rajendran, 2001 and 2002) have raised the possibility that the observed morphology was a factor of two smaller than that reported by Baker, and that its current elevation of $<3 \mathrm{~m}$ crest-to-base is caused partly by the 1819 event and partly by pre-1819 earthquakes. A difficulty in rejecting Baker's survey, a canal engineer of repute, is that he would have made vertical errors of less than a few $\mathrm{cm}$ in measuring topography over the 10 $\mathrm{km}$ width of the Allah Bund. Thus an error of 2$3 \mathrm{~m}$ can be rejected. The cross-section that was intended to accompany Baker's account was drafted from a larger scale survey deposited with the Sind government. The smaller version 
published by Oldham included a typographical error in the vertical scale, but it is unlikely that gross drafting errors would have been introduced. Moreover, the accompanying map view of the river system is exact in many details compared to recent satellite photos suggesting that its execution was fastidious

Several explanations can be invoked to reconcile the leveling data and current morphology. The first is that the uplift and subsidence morphology may have changed since the earthquake. For example, it is possible that Baker's measurements started at a lower vertical datum than that available to the Rajendrans in 2000. According to Burnes (1833) the footwall subsided by $1-3 \mathrm{~m}$, with maximum subsidence near the scarp. Burnes's two handwritten accounts in the Geological Society of London describe slightly different views of the river cut through the Allah Bund in 1827 and 1828 that suggest it was evolving in response to the flood of 1826. Currently the sediments of Lake Sindri slope upwards towards the southern edge of the Allah Bund. In the past 180 years sediments eroded from the front of the scarp, supplemented by sediments from the Narra River in flood, would have filled any depression fronting the scarp along the northern shore of Lake Sindri resulting in a datum possibly $2 \mathrm{~m}$ higher than that available to Baker. The Rajendrans were unable to map vertical profiles northward into the Sindh province of Pakistan hence it may not have been possible to recover Baker's northern datum.

A second possibility is to assume that the southern edge of the Allah Bund has now been eroded $1 \mathrm{~km}$ or more northward by monsoon winds and floods driving waves across the 30$50 \mathrm{~km}$ wide fetch of open water to its South. In 1827 the crest of the scarp was fewer than 600 $\mathrm{m}$ from its southern edge. Ablation of the crest of the Allah Bund may have also occurred although this is considered unlikely because Rajendran and Rajendran report the survival of surface geodetic monuments installed in 1860 .

The subsidence deformation profile, now buried beneath Lake Sindri, may in fact be better preserved than the uplift profile, and this, at some future date, may provide additional constraints of slip in the 1819 earthquake. The depth of frontal fill and co-seismic slip could be tested with suitable excavations, or seismic profiles, of the northern edge of the bed of Lake Sindri.

While excavations of Sindri sedimentation might clarify the discrepancy between historic leveling and current morphology, the observation by Rajendran and Rajendran that two or more earthquakes caused incremental changes in the height of the Allah Bund requires downward revision of the $11 \mathrm{~m}$ estimate of coseismic slip to a more modest $5 \mathrm{~m}$. Any further reduction in the coseismic uplift of the Allah Bund can be rejected based on Baker's mapping of the elevation of the bed of the Narra River since this would have been at river base-level before the earthquake, unaffected by previous earthquakes.

The recent 26 January 2001 Bhuj earthquake was associated with 3-6 m of slip (Bendick et al., 2001). Since this occurred on a $40 \times 40 \mathrm{~km}$ rupture, and resulted in isoseismal intensity distributions throughout India similar to the 1819 earthquake (Hough et al., 2002), it is tempting to assume that the two events had similar stress drops and local attenuation relationships, and somewhat similar geometry and magnitude. This would require the along-strike length of the Allah Bund earthquake to be shortened considerably below the $>100 \mathrm{~km}$ length first suggested by Oldham and adopted by all later authors. In contrast, Ambraseys and Douglas (2004) favor a $M_{w}=8.19$ magnitude for this event, requiring rupture dimensions consistent with those inferred by Oldham (1928).

\section{Himalayan earthquakes 1 September 1803 and 26 August 1833}

These earthquakes occurred at the western and eastern ends of the inferred 6 June 1505 earthquake. The first of these events occurred during the opening battles of the 2nd war against the Mahrattas. In late August 1803 a British Army had laid seige to the fort and town of Aligarh on the banks of the Calini River (between the Ganges and Jumna) some $200 \mathrm{~km}$ from the Himalaya. The commander of the British Army, Lt. General Lake, writing to Wellesley on 1 September indicates that the strength of the defences will require a one month seige. Yet, not three 
days later Lake writes again to Wellesley that they have successfully stormed the town with minor loss of life. In contrast to Lake's silence on the earthquake that occurred between the two letters, a member (Thorn, 1818) of the besieging army describes violent shaking for 2 minutes at midnight accompanied by collapse several buildings. The earthquake appears in part responsible for the successful capture of the fort, either from damage to its walls or distress to inhabitants, although specific details are lacking.

A summary of materials available for the 1803 event is recorded by Ambraseys and Jackson (2003) who assign it an approximate magnitude of $M_{w}=7.5$. This was later revised to $M_{w}=8.09$ by Ambraseys and Douglas (2004) using additional materials, who place it at the weatern end of the 1505 rupture. The 1833 erathquake almost exactly 30 years later occurred at the eastern end of the 1505 rupture. In contrast to the extensive damage reported from Tibet in 1505, few accounts of damage have surfaced from Tibetan sources for these two earthquakes, suggesting that they were significantly less severe than the 1505 event. The one exception to the apparent silence from Tibet for the 1833 earthquake are accounts of damage from members of the Nepal quinquennial tribute delegation returning from Beijing who brought with them accounts of the increasing damage they encountered as they approached the northern Nepal border (Bilham, 1995).

The $M_{s} \geq 7.7$ August 1833 earthquake near Kathmandu consisted of three shocks (Bilham, 1995). The first caused alarm and the second, 5 hours later, brought most people from their homes. The mainshock $\left(M_{w}=7.69\right.$, Ambraseys and Douglas, 2004) occurred 15 minutes later causing widespread structural damage in India and Nepal, but the combined loss of life in India and Nepal was only 500 because most people were already in the open, alarmed by the two foreshocks. Newspaper reports of these events are abundant as are scientific commentaries in journals in India and Europe. The isoseismals from this earthquake suggest an epicentral region similar to, or at the western end of, the $1934 M_{s}=8.1$ rupture, which together with the multiple shocks in the event, raises a number of interpretational difficulties. The earthquake did not affect western Nepal and its magnitude is too small to have had much effect on releasing strain accumulated since the 1505 earthquake. However, had it occurred on the plate boundary «detachment fault» it could not have released much of the slip available to drive the larger magnitude 1934 earthquake a century later. Since the 1934 earthquake is believed to have released up to $8 \mathrm{~m}$ of slip, and since potential plate-boundary slip is renewed at a rate of less than $2 \mathrm{~m}$ per century, the 1833 rupture would have had to occur on different fault systems or to have slipped on a small patch contiguous to the 1934 rupture. One possibility is that one or more of the three 1833 earthquakes occurred deep in the Indian plate where both strike-slip and thrust faulting can occur, or that all three earthquakes were $M \geq 7.5$ thrust earthquakes at the Northern edge of the 1934 rupture zone, similar to those that have occurred in the past several decades in western Nepal.

\section{Cachar 10 January 1869}

This $M>7$ earthquake occurred in the Sylhet region (Silchar) of what is now NE Bangladesh. Although numerous accounts of this earthquake were compiled by the Oldhams the data are insufficient to estimate a causal fault or a precise magnitude. Ambraseys and Douglas (2004) estimate $M_{w}=7.39$. The most likely fault to be associated with this earthquake is the eastern extremity of the Dauki fault, as hinted by Godwin-Austin (1869) who was undertaking firstorder triangulation in the region at the time. Few first hand accounts of the event exist outside the covers of Oldham (1884) but the occasional letter describing its effects surfaces. An example is reproduced below:

«The earthquake has not been a single shock but has lasted, on and off, a month - nay it is said some of the shocks have gone on rocking for five minutes by the watch till some people were literally sea sick. The bazaar at Silchar (the capital of Cachar) is the handsomest street anywhere east of Calcutta and it has been engulfed. i.e. it has gone bodily down not at once but in a series of descents, some ten feet at a 
time. The river in Silchar in the cold weather runs about 50 feet below the level of its banks which are only dried mud, and the country has been so rocked up and down till the river has cut its banks right down to its own level and the plain at Silchar is all one debris with no particular river anywhere. The commissioner told me on Monday last that it was officially reported that the only thing left standing at Silchar was Clarke's bridge, and it was the most wonderful sight that ever was seen.» (Clarke, 1869)

The dangers of speculating on a causal fault or mechanism for the 1869 earthquake are highlighted by radical errors of a century of interpretations of the 1897 earthquake that were shown to be baseless once the geodetic signal was assessed in 2001. It is possible that enough of the 1869 geodetic survey network was in place prior to the earthquake to render its remeasurement even now of value.

\section{The 31 December $1881 M_{w}=7.9$ Car Nicobar earthquake}

This earthquake caused minor damage in the Andaman Island Penal colony and generated a tsunami that was observed throughout the Bay of Bengal but not along the Burmese coast. The tsunami did no damage around the Bay of Bengal where tide gauges recorded a maximum amplitude of $0.8 \mathrm{~m}$ (Oldham, 1884). An analysis of five tide gauge records reveals that the earthquake was $M_{w}=7.9 \pm 0.2$ and occurred on an east-dipping thrust fault below and to the west of Car Nicobar, an island at $9^{\circ} \mathrm{N}$ midway between the Andaman and Nicobar islands (Ortiz and Bilham, 2003). GPS measurements at Port Blair indicate oblique convergence of the plate boundary (Paul et al., 2001). The earthquake is believed to have occurred on the interface between the Indian and Andaman Plates and the inferred mechanism of westward slip of the hanging wall slip is consistent with slip partitioning between the dipping subduction zone, and the strike-slip west Andaman fault east of Car Nicobar.

A feature of this earthquake is the inferred presence of a region of minor slip NE of the main rupture zone. This may have been a sec- ondary earthquake triggered by the mainshock. Its timing would have to have occurred within a few minutes of the mainshock for it to have produced the sea wave observed at Port Blair. Local populations were concentrated in only two islands and therefore there is no corroboration of this inferred northern region of submarine faulting which occurred between them. It is probable that offshore corals may be of use in reconstructing an extended history of earthquakes in the Andaman-Nicobar Islands. The island of Car Nicobar is believed to have been raised and tilted during the 1881 event. Deformation models that do not include this uplift result in an inappropriate estimate of the observed tsunami runup on the island (Ortiz and Bilham, 2003).

\section{1897 Shillong Plateau Earthquake}

The 1897 Great Assam earthquake $\left(M_{s}=8.0\right)$ for more than a century was believed to have occurred on a thrust fault dipping gently to the north. Some considered it to have been a Himalayan basal thrust. We now recognize that the earthquake occurred on a reverse fault dipping steeply to the south. Slip during the 1897 earthquake may have exceeded $16 \mathrm{~m}$, resulting in 10 $\mathrm{m}$ uplift of the northern edge of the plateau.

Oldham clearly recognized the value of surface deformation as a quantitative measure of what happens in an earthquake, but the analytical tools to interpret these data were not to emerge for a further half century. In 1897 correspondence with the Surveyor general, Sydney Burrard, Oldham requested a geodetic re-survey of the Shillong Plateau. The work undertaken by J. Bond covered only the southern half of the plateau and was considered by Burrard (1898) to be inferior in accuracy to normal survey standards because numerous triangles did not close precisely. (A test of survey accuracy is whether angles in a triangle after correcting for spherical excess add up to $180^{\circ}$ ). We now know that these misclosures were probably due to postseismic adjustments in the epicentral region continuing after the earthquake. The 1897 displacement results available to Oldham were ambiguous: either the plateau had bodily expanded and risen with no southward motion, or it had risen with- 
out strain and moved southwards by slip on the Dauki fault bordering its southern edge. Realizing this, Oldham urged resurvey of the northern half of the plateau but he was destined never to see the data since it was completed in 1936, the year he died (Davison, 1936). Analyses of angle changes between 1869 and 1936 reveal that Oldham's instincts were correct. The fault that slipped in 1897 was a 110-km-long blind reverse fault beneath the northern edge of the plateau, dipping southward at $45^{\circ}$ with $16 \pm 5$ $\mathrm{m}$ of slip between 9 and $39 \mathrm{~km}$ (Bilham and England, 2001). We named this unmapped fault the Oldham Fault in his honour.

The earthquake raised the northern edge of the plateau roughly $10 \mathrm{~m}$. The causal fault is believed to have cut right through the lower crust but did not approach closer than $9 \mathrm{~km}$ to the Earth's surface. Oldham (1899) photographed secondary faulting of up to $10 \mathrm{~m}$ at the western end of the plateau on the Chedrang fault. The $1.6 \mathrm{~km}$ mean-height of the plateau surface appears to have been driven to its current position by reverse faults acting on both its northern and southern edges. Three dissected terraces border the northern edge of the plateau that may be separated by active faults, but none have been mapped by geologists possibly due to the thick forest cover that makes access difficult.

Enigmatic aspects of this earthquake concern the uniqueness of the Shillong plateau which permits contraction of the Indian plate within 80 $\mathrm{km}$ of the Himalaya convergence zone, thereby reducing the productivity of Himalayan earthquakes. An uplift rate of $2.5 \pm 1 \mathrm{~mm} / \mathrm{yr}$ can be calculated from the current elevation of the plateau, and from the date of its initial elevation estimated from changes in sedimentation styles in northern Bangladesh. This convergence requires a convergence rate of $4 \pm 2 \mathrm{~mm} / \mathrm{yr}$, or approximately a factor 4 less than the India/Tibet convergence rate (Bilham and England, 2001). The only large historical earthquake known in the Bhutan Himalaya is the 1713 event described in Ambraseys and Jackson (2003) and the precise location of this event is far from certain.

The southern edge of the Shillong Plateau is truncated by the Dhauki fault. In order that the surface of the Plateau be horizontal the Dhauki fault must also act as a reverse fault, and this raises additional concerns. No historical earthquakes have been recorded on this fault, and many previous studies interpret the fault as a dextral strike-slip fault. Although the fault may have slipped differently in the past there is little doubt that reverse slip is now the prevailing mechanism, and has been so for the past one or two million years. Earthquakes beneath the plateau have thrust mechanisms parallel to the strike of the Oldham fault at depths of more than $35 \mathrm{~km}$. The 1869 Cachar earthquake described by the Oldhams may have occurred at the Eastern end of the Dhauki fault (GodwinAustin, 1869; Oldham, 1884).

A recent review of instrumental records of the 1897 earthquake reveals its teleseismically derived magnitude to be $M_{s}=8.0$ (Ambraseys, 2000 ) effectively the same as its geodetic seismic moment of $M=8.1$ (Bilham and England, 2001). A re-evaluation of Oldham's 1897 isoseismal intensity data supplemented by additional data from newspapers, diaries, books and government reports unavailable to Oldham, reveal significantly reduced areas for contours of I > VIII isoseismals, but similar areas for lower intensity shaking. The newly evaluated intensities include data from Tibet and Bhutan (Ambraseys and Bilham, 2003c).

\section{Kangra $1905 M=7.8$ earthquake}

Occurring just 7 years after the 1897 Assam earthquake, the Kangra event found the geologists of India eager to map the details of the event. The earthquake had its oddities - in particular a prominent epicentral region of RossiForel shaking of intensity VIII to X near Kangra and Dharmsala and an island of VIII shaking almost $250 \mathrm{~km}$ to the SE near Dehra Dun. This, and an artificially-inflated estimate for magnitude (Richter rounded Gutenberg's calculated magnitude upward from $M=7.8$ to $M=8$; see Ambraseys and Bilham, 2000), led several investigators to assume that rupture may have extended more than $350 \mathrm{~km}$ along strike.

Although geodetic measurements existed along the probable southern edge of the rupture, no remeasurements were made after the earthquake except near the remote region of high ac- 
celerations near Dehra Dun. No horizontal deformation was detected and a vertical deformation signal, though discussed by many subsequent investigators, has recently been dismissed as an artifact of the leveling process (Bilham, 2001). Hence there is little evidence to believe that its rupture exceeded $200 \mathrm{~km}$. First-order triangulation prior to the earthquake is limited to the southern edge of the inferred rupture zone and it appears not to have been re-measured since its initial measurement in 1845. An interpretation of a GPS occupation of some of these points in 2001 is currently underway. Intensities of this event are re-evaluated by Ambraseys and Douglas (2004)

\section{Discussion}

The above review of early earthquakes and case histories of some of the larger earthquakes, omits numerous smaller ones felt by individuals or communities. The larger ones form a patchy history that may be complete for the past 200 years, but which is certainly missing many large earthquakes before then. An important question is whether there is scant information on pre-muslim or medieval earthquakes because there were few events, or whether it is because we have no records of them. Although this question cannot be answered from the historical record alone we may consider extreme scenarios as a guide to future searches to resolve the issue.

Aggravating our lack of knowledge of previous earthquake is the curious observation that none of the numerous earthquakes that have occurred in India and the Himalaya in the past several centuries have produced surface ruptures, with the exception of secondary surface faulting in the 1897 earthquake (Oldham, 1898), and surface fractures of the 1993 Latur earthquake (Seeber et al., 1996). In 1505 and 1892 surface faulting was observed at the surface along the Pakistan/Afghanistan border (Ambraseys and Bilham, 2003a) but no surface faulting has ever been reported in the Himalayan and Indo-Burman plate boundaries, despite geological indications that surface rupture of the frontal faults has occurred in the past (Wesnousky et al., 1999).
The primary ruptures of the largest mid-plate events of the past two centuries, the $7.8<M<8.1$ 1819 Allah Bund, the $M=8.11897$ Shillong, the $M=7.31931$ Mach, and the $M=7.62001$ Bhuj earthquakes have all been on blind thrust faults, dipping at approximately $45^{\circ}$, terminating 1-9 $\mathrm{km}$ below the surface, and extending to the base of the crust. Thus, although they have caused widespread destruction in the historical record, the geological manifestation of their passage is limited to secondary cracks and liquefaction phenomena that tell us little about their mechanisms. Such knowledge about rupture geometries as we have obtained for these earthquakes, with the exception of the most recent, has been derived almost entirely from sparse geodetic data.

The conclusion to be derived from this absence of surface ruptures in the subcontinent is that many historical earthquakes occurred on faults that are currently unmapped, and the corollary is that there may exist many hundreds of subsurface faults potentially awaiting re-activation for which we have no geological intelligence.

The mechanisms of the numerous smaller shocks that appear in historical Indian catalogues must be inferred from modern focal mechanisms in those same geographic settings. The inherent problem in doing this is that focal mechanisms in some parts of India, e.g., the Himalayan foothills, vary with depth. Surviving intensity data are rarely adequate to distinguish between deep and shallow shocks.

\subsection{Intensity and attenuation}

Estimates of intensities for the two largest earthquakes of the past two centuries (1905 and 1897) have revealed that previous estimates of Rossi-Forel or Modified Mercalli intensity tend to exaggerate high intensity shaking by 1-3 intensity units (Ambraseys and Bilham, 2003c) whereas lower intensities (V-II) are estimated with reasonable accuracy. The reason for this exaggeration is that the style of building construction suffers significant damage at intensities around VII-VIII and that subsequent shaking produces somewhat imperceptible additional damage (Ambraseys and Bilham, 2003b). 
Even quite recent intensity estimates can be suspect. For example, the 1989 Udaypur earthquake in southern Nepal resulted in both Nepali (Pandey and Nicolas, 1989; Dikshit and Koirala, 1989) and Indian (Sinha, 1993) intensity and engineering damage studies. The resulting intensity contours show an abrupt jump of 1-1.5 intensity units at the Nepal/India border where the two studies abut.

The re-evaluation of the felt intensity reports for the 1833, 1897, 1905, 1934 and 1950 earthquakes on a common scale is an important priority, that has been partly completed by Ambraseys and Jackson (2003), since it may reveal the details of seismic hazards in intervening regions where future Himalayan earthquakes are anticipated. Currently more than three scales have been used to report these data. Rossi-Forel, Modified Mercalli and MSK intensities, with caveats imposed by their specific inapplicability to Indian building methods. In some areas acceleration damage can only with difficulty be distinguished from collapse caused by liquefaction-induced foundation failure. In 1897 regions of extensive liquefaction and catastrophic lateral spreading follow the banks of the main rivers and result in building damage from foundation collapse, rather than grades of shaking intensity. Ambraseys and Bilham (2003c) separated liquefaction observations from MSK assignations based on shaking intensity lest they bias the areas of isoseismal contours.

\subsection{Himalayan recurrence interval}

The recurrence interval for great Himalayan earthquakes remains conjectural since the historical record is probably incomplete even for the past 500 years. A summary of those events for which we have data is depicted in fig. $4 a, b$, although both the rupture area and the amount of slip are unknown for each of these events. The figure suggests that the western Himalaya may have slipped in a sequence of events between 1501 and 1555, and that since then there have been relatively modest earthquakes, insufficient to release the $1.5-1.8 \mathrm{~m}$ per century of accumulating convergence revealed from geodetic measurements. The largest of the pre-1900 earth- quakes, the 6 June 1505 Kumaon/western Nepal earthquake (Jackson, 2002; Ambraseys and Jackson, 2003), may have exceeded $M_{w}=8.2$, and its recurrence now would result in a similarsized earthquake (9 m of slip along a 500-600 $\mathrm{km}$ rupture zone). Damage in northern India was considerable during the 1505 event and it is likely that its recurrence would damage many of the large cities along the Ganges and Jumna rivers through shaking, and from the effects of extensive liquefaction. Smaller seismic gaps are evident in Kashmir, in Sikkim and in Assam for which the historical record is ambiguous or absent.

Assuming that seven to ten great ruptures permit the slip of the entire Himalayan Arc, and a recurrence interval of 500 years $(\geq 9 \mathrm{~m}$ slip on 200-300 km long, 70-90 km wide, ruptures) we should anticipate $M \geq 8$ earthquakes occurring every 50-70 years. Insufficient earthquakes have occurred recently to match this estimate. Two great earthquakes only that approach this severity have occurred in the past 200 years (1934 and 1950), and two others are known in the previous 300 years (Kashmir, 1505, 1555). No great earthquake has occurred for 53 years. Almost two thirds of the Himalaya remain unbroken by recent earthquakes, suggesting that several seismic gaps may currently exist. Finally, the summation of seismic moment from all known earthquakes since 1505 along the entire arc yields a slip rate less than $30 \%$ of that derived from the current geodetic slip rate (Bilham and Ambraseys, 2004).

From these arguments we may form one of two conclusions: that one or more great $\mathrm{Hi}-$ malayan earthquakes are overdue, or that our understanding of the way in which the northern plate boundary slips is flawed. The case for the imminent failure of a seismic gap is hampered by the absence of any well documented recurrence interval, or indeed any evidence for regular failure of the Himalayan plate boundary. The absence of constraint permits the extreme view, for example, that failure occurs in clustered sequences, as may have occurred in the western Himalaya 1400-1555. If indeed this sequence released accumulated displacements in the western Himalaya five centuries ago, then a case can be made for the immediate recurrence 

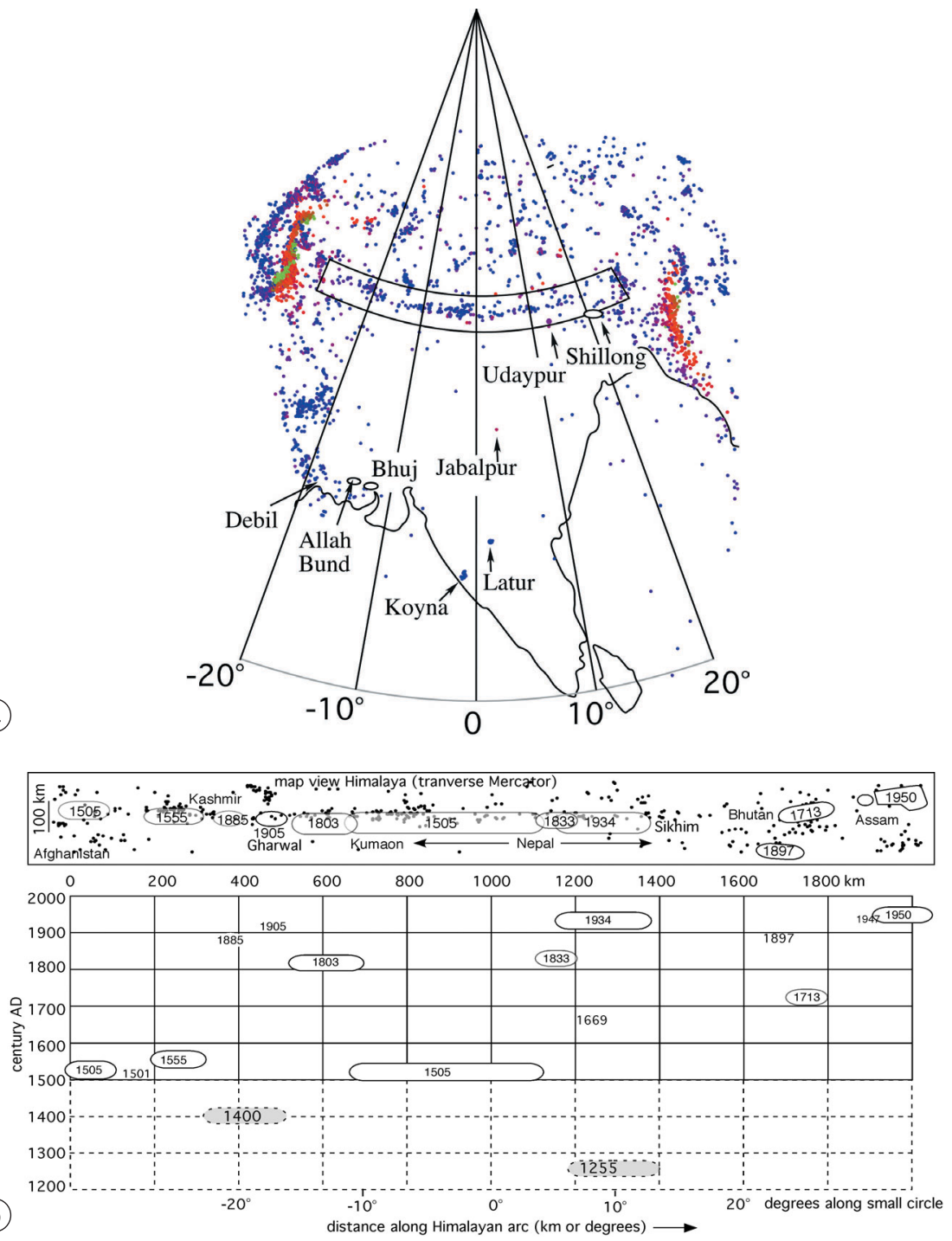

Fig. 4a,b. a) The Himalaya describe a small circle that subtends an arc of approximately one radian symmetrically about the Thakola Graben in Tibet. Important mid-plate earthquakes named. Microseismicity follows this small circle (from Engdhal et al., 1998) and is negligible to its south where great earthquakes are located. b) The arcuate box is expanded (and straightened) and it shows time distance plot of approximate rupture areas of large earthquakes in the past eight centuries plotted along the arc (approximate transverse-Mercator projection of linear transverse-km versus angular distance). One or more large earthquakes appear to be overdue in Kashmir, Kumaon and Western Nepal. We know of no earthquakes in Sikkim, and the 1897 Assam Shillong earthquake may have reduced the slip potential in Eastern Bhutan. Pre-1500 earthquakes are known with less certainty. Trench studies have revealed slip on the frontal thrusts at the beginning of the 15th century at several locations west of Dehra Dun (Senthil Kumar, per. comm., 2004) and surface rupture on frontal thrusts in eastern Nepal may correspond to the earthquake that destroyed Kathmandu in 1255 (Rockwell, pers. comm., 2004). 
of one or more $9 \mathrm{~m}$ slip events, based on the current convergence rate of $18 \mathrm{~mm} / \mathrm{yr}$. The region of the 1505 earthquake has been hitherto termed the Central Himalayan seismic gap by Khattri and Tyagi (1983) and Khattri (1987).

Alternatively, the assumption that great earthquakes are essential features for plate boundary slip may be incorrect - the Himalaya may fail in smaller events that incompletely rupture the plate boundary. These smaller events might be considered to be similar to the ChiChi earthquake of 1999 that ruptured through a midlevel segment of the accretionary wedge, rather than through a basal detachment. Such events may accommodate convergence without translating the entire Himalaya southward over India. The major 1833, 1885 and 1905 earthquakes $\left(7.5<M_{w}<7.8\right)$ may have been examples of these «out-of-sequence thrusts».

One of the most troubling observations, that might be accounted for by out-of sequence thrusting or deep events, is that no recent $\mathrm{Hi}$ malayan earthquake has ever resulted in a recorded surface rupture. Such ruptures have obviously occurred in recent geological time, on the main frontal thrusts for example (Wesnousky et al., 1999), signifying either that recent earthquakes are anomalously small, or that the search for surface rupture may not have been exhaustive. If some, but not all, great earthquakes rupture the Himalayan frontal thrusts we cannot hope to quantify the recurrence interval from these events using paleosismic fault-trenching methods.

Out of sequence thrusts cannot represent a steady-state condition for Himalayan slip since it would not explain the geological observation of occasional slip on the basal thrust systems and Main Frontal Thrusts. However, it is possible that excessive recent erosion of the Himalayan foothills may have upset the uniform taper of the Himalayan accretionary wedge such that adjustments are now underway that result in a predominance of high-level thrusting interspersed with infrequent basal thrusts.

Historical studies have an important role in distinguishing between these various scenarios, yet it is unlikely that we shall ever find a history that is complete across- and along- the Himalaya, even near the Kathmandu and Kashmir Valleys that have been administered continuously by a record-keeping population for the past thousand years. For this reason, trench investigations of faults and liquefaction features will be necessary to fill in the record. In practice, the subsurface record of strong-ground motion is complete, but its interpretation may be non-unique, suitable conditions may not exist everywhere for it to be recorded, and it is insensitive to small earthquakes whose recurrence may be quite damaging.

\subsection{Mid-plate recurrence intervals}

Although numerous micro-earthquakes, and many damaging shocks have occurred in the past several centuries in India, the geodetic stability of the plate, and the absence of recent mountain ranges indicates that earthquakes should not recur repeatedly on the same fault during the written history of India. Yet archeological observations in India suggest earthquakes may have repeatedly destroyed early settlements there, especially in westernmost India. Rajendran et al. (1996) present evidence for reactivation of the fault causal to the Latur earthquake. The town of Latur itself, like many Indian villages, is a mound city built on the ruins of previous cities.

The occurrence of the $M=7.6$ Bhuj 2001 earthquake less than two centuries after the $M \geq 7.8$ Allah Bund 1819 earthquake has been considered by some investigators to represent a short recurrence interval for earthquakes in mid-plate India. Such an appraisal would be incorrect because the two events did not, of course, rupture the same fault, nor even the same fault system. The two earthquakes occurred on the ancient Kachchh rift zone, an east-west fault system that can be traced structurally from near Karachi to Ahmedabad. In a study of the 1819 event it was concluded that contiguous future faulting might be anticipated, with specific concern that rupture to the west would create hazards for Karachi (Bilham, 1999). As it happened, rupture in 2001 occurred 2-4 rupture lengths to the east of the 1819 earthquake. Hence there is a possibility that the entire Kachchh rift may be converging. In fact geodetic data suggest that the rift north of the 
Bhuj region may have converged by more than $1 \mathrm{~m}$ since 1856 (Sri Devi et al., 2003). Should this be the case, additional large earthquakes may be anticipated both to the east and west of the 1819 and 2001 earthquakes.

The observed geodetic convergence of the Rann of Kachchh by $9 \pm 3 \mathrm{~mm} / \mathrm{yr}$ is approximately 2-3 times larger that the entire geodetic convergence rate between Northern and Southern India (Paul et al., 2001). Two explanations for this have been proposed: one is that a $400 \mathrm{~km}$ wide continental «Sindh flake» is in the process of fracturing from the NE edge of the Indian plate (Stein et al., 2002), the other is that the interconnected ancient rift systems of northern India define a small northern plate « the Harappan plate» that allows a large triangle in NE India between the central Himalaya and Bhuj to converge with the main body of the Indian plate to the south (Bilham et al., 2003). Support for either mechanism of plate fragmentation is weak, and future geodetic observations are needed to resolve the extent of plate deformation in NE India.

\section{Conclusions}

The tectonic setting of India's collision with Asia is now reasonably well characterized from recent seismicity and geodetic studies of relative motion at their plate boundaries. Direct measurements across and within the Himalaya reveal a locking line beneath the edge of the $\mathrm{Ti}$ betan Plateau and the absence of creep to its south (Bilham et al., 1995, 1998, 2001), implying that the advance of the Himalaya over the Indian plate proceeds largely through the recurrence of great plate boundary earthquakes.

Earthquakes within the Indian plate are attributable to the superposition of the NW compressional stress of collision, on the stresses arising from plate flexure. The depth and mechanisms of recent earthquakes reflect the sense of these combined stresses.

A several millennia-long written record in India has revealed few major earthquakes prior to the past two centuries. This is partly due to the fact that extant records have yet to be searched rigorously for earthquakes, but is in part due to the corruption of potentially valu- able records and their loss through fire, war and decay. Despite their sparseness it is likely that documents on historical earthquakes will surface in Tibetan, Urdu and Arabic records that will change current estimates of the significance of seismic gaps in the Himalaya, and may change our understanding of earthquakes within the Indian continent.

Our current understanding of Himalayan earthquakes is such that we may calculate potential slip in several segments of the plate boundary, but we cannot estimate the timing of future events. Making assumptions about the probable completeness of the historical seismic record we can estimate estimate minimum slip potential based on the time since the last known earthquake (Bilham et al., 2001). This has moderate relevance to planning for future earthquakes. The eventual establishment of recurrence intervals for $\mathrm{Hi}$ malayan ruptures will require a combination of serendipitous historical studies and geological trench investigations of faulting and earthquake-induced liquefaction features.

\section{Acknowledgements}

R.S. Cox of the American Philosophical Society provided a copy of C.B. Clarke's letter concerning the Silchar earthquake. I thank the organizers of the Erice conference on historical earthquakes for inviting my participation. I also thank an anonymous reviewer for amusing and insightful comments on the first draft of this article. The study was funded by the National Science Foundation EAR-0003449.

\section{REFERENCES}

Ambraseys, N.N. (2000): Reappraisal of north Indian earthquakes at the turn of the 20th century, Curr. Sci., 79, 101-114.

AmbRASEYS, N.N. (2004): A note on three little-known early earthquakes in India, Curr. Sci., 86 (4), 506-508.

AmbraseYs, N.N. and D. JACKSON (2003): A note on early earthquakes in northern India and southern Tibet, Curr. Sci., 84 (4), 571-582.

Ambraseys, N.N. and R. Bilham (2000). A note on the Kangra $M s=7.8$ earthquake of 4 April 1905, Curr. 
Sci., 79 (4), 101-106

Ambraseys, N.N. and R. BiLham (2003a): Earthquakes and crustal deformation in northern Baluchistan 18922001, Bull. Seismol. Soc. Am. 93 (4), 1573-1600.

Ambraseys, N.N. and R. BILHAM (2003b): Earthquakes in Afghanistan, Seismol. Res. Lett., 74 (2), 107-123.

AmbRASEYS, N.N. and R. BILHAM (2003c): MSK Isoseismal intensities evaluated for the 1897 Great Assam Earthquake, Bull. Seismol. Soc. Am., 93 (2), 655-673.

Ambraseys, N.N. and J. Douglas (2004): Magnitude calibration of North Indian earthquakes, Geophys. J. Int. (in press).

BAIRD-SMITH, R. (1843a): Memoir on Indian earthquakes, Part I, J. Asiatic Soc. Bengal, 11, 1046-1054.

BAIRD-SMith, R. (1843b): Memoir on Indian Earthquakes, Part II, J. Asiatic Soc. Bengal, 12 (2), (New Series, 136), 1029-1056.

BAIRD-SMith, R. (1844): Memoir on Indian Earthquakes, Part III, J. Asiatic Soc. Bengal, 156, 964-983.

BAKER, W.E. (1846): Remarks on the Allah Bund and on the drainage of the Eastern part of the Sind Basin, Trans. Bombay Geog. Soc., 7, 186-188.

BAPAT, A., R. KULKARNI and S. GUHA (1983): Catalogue of earthquakes in India and neighbourhood from historical period up to 1979, Indian Soc. Earthquake Eng., Roorkee.

BENDICK, R. and R. BILHAM (1999): Search for buckling of the southwest Indian coast related to Himalayan collision, in Himalaya and Tibet: Mountain Roots to Mountain Tops, edited by A. MACFARLANE, R. SORKHABI and J. Quade, Geol. Soc. Am. Spec. Pap. 328, 313-323.

BENDICK, R. and R. BILHAM (2001): How perfect is the Himalayan Arc?, Geology, 29, 791-794.

Bendick, R., R. Bilham, E. Fielding, V.K. Gaur, S. Hough, G. Kier, M.N. Kulkarni, S. Martin, K. Mueller and M. MuKul (2001): The January 26, 2001 «Republic Day» Earthquake, India, Seismol. Res. Lett., 72 (3), 328-335

Bilham, R. (1994): The 1737 Calcutta Earthquake and Cyclone Evaluated, Bull. Seismol. Soc. Am., 84 (5), 16501657.

BILHAM, R. (1995): Location and magnitude of the 1833 Nepal earthquake and its relation to the rupture zones of contiguous great Himalayan earthquakes, Curr. Sci., 69, 101-128.

BILHAM, R. (1999): Slip parameters for the Rann of Kachchh, India, 16 June 1819, earthquake, quantified from contemporary accounts, in Coastal Tectonics, edited by I.S. Stewart and C. Vita-Finzi, Geol. Soc. London Spec. Publ. 146, 295-318.

BILHAM, R. (2001): Slow tilt reversal of the Lesser Himalaya between 1862 and 1992 at $78^{\circ} \mathrm{E}$, and bounds to the southeast rupture of the 1905 Kangra earthquake, Geophis. J. Int., 144, 1-23.

Bilham, R. and N.N. Ambraseys (2004): Apparent Himalayan slip deficit from the summation of seismic moments for Himalayan earthquakes, 1500-2000, Curr. Sci. (in press).

Bilham, R. and P. ENGLAND (2001): Plateau «pop-up» in the great 1897 Assam earthquake, Nature (London), 410 (6830), 806-809.

BILHAM, R. and V.K GAUR (2000): Geodetic contributions to the study of seismotectonics in India, Curr. Sci., 79
(9), 1259-1269

BILHAM R., P. BODIN and M. JACKSON (1995): Entertaining a great earthquake in western Nepal; historic inactivity and geodetic tests for the development of strain, $J$. Nepal Geol. Soc., Kathmandu, 11, 73-88.

Bilham, R., K. Larson, J. Freymueller and Project IDYLHIM MEMBERS (1997): GPS measurements of presentday convergence across the Nepal Himalaya, Nature, London, 386, 61-64.

BILHAM, R., F. Blume, R. BENDICK and V. K. Gaur (1998): Geodetic constraints on the Traslation and Deformation of India: implications for future great Himalayan earthquakess, Curr. Sci., 74 (3), 213-229.

Bilham, R., V.K. GaUR and P. Molnar (2001): Himalayan Seismic Hazard, Science, 293, 1442-1444.

Bilham, R., R. Bendick and K. Wallace (2003). Flexure of the Indian Plate and Intraplate Earthquakes, Proc. Indian Acad Sci., Earth Planet Sci., 112 (3), 1-14.

BuRNES, L.A. (1833): A memoir of the eastern Branch of the Indus giving an account of the alterations produced in it by the earthquake of 1819 and the bursting of the dams in 1826; also a theory of the Runn's formation and some surmises in the route of Alexander the Great, presented by the Hon'ble the Governor in Council to the Lit. Soc. of Bombay. Camp at Lucput, 28 March 1827,13 August 1828 (manuscript presented by the author to the Geol. Soc. London 18 December 1833 with map inscribed W. Ballantine 1831).

Chandra, U. (1977): Earthquakes of Peninsular India - A seismotectonic study, Bull. Seismol. Soc Am., 67 (5), 1387-1413.

Chitrakar, G.R. and M.R. PANDEy (1986): Historica earthquakes of Nepal, Bull. Geol. Soc. Nepal, 4, 7-8.

Clarke, C.B. (1869): Letter to father (American Philosophical Society, Philadelphia), ms.

Curray, J.R, F.J. Emmel, D.G. MoOre and R.W. RaitT (1982): Structure, tectonics and geological history of the NE Indian Ocean, in The Indian Ocean: The Ocean Basins and Margins, edited by E.M. NARRIN and F.G. SEHLi (New York, Plenum Press), 399-450.

Curray, J.R., F.J. Emmel, D.G. Moore, R.W. Raitt, M HENRY and R. KIECKHEFER (1979): Tectonics of the Andaman sea and Burma, in Geological and Geophysical Investigations of Continental Margins, edited by J.S. Watkins, L. Montadert and P. Dickerson, AAPG Memoir, 29, 189-198.

DAVISON, C. (1936): R.D. Oldham: obituary, Nature, 138, 316-317.

Dikshit, A.M. and A. KoIRALA (1989): Report on the Intensity Mapping of Udaypur Earthquake of 20 August 1988 (HMG Ministry of Industry, Nepal, Dept. of Mines and Geology, Lainchaur, Kathmandu).

DunBAR, P.K., P.A. LOCKRIDGE and L.S. WHITESIDE (1992): Catalog of significant earthquakes, including quantitative casualties and damage (National Oceanic and Atmospheric Adminstration, National Environment Satellite Data and Information Service, National Geophysical Data Center), Report SE-49, pp. 320.

Dunn, J.A., J.B. Auden, A.M.N. Gosh and S.C. RoY (1939): The Bihar-Nepal Earthquake of 1934, Mem. Geol. Soc. India, Surv. India, Calcutta, 73, pp. 391 (reprint, 1981).

ENGDAHL, E R, R.D. VAN DER HILST and R.P. Buland 
(1998): Global teleseismic earthquake relocation with improved travel times and procedures for depth determination, Bull. Seismol. Soc. Am., 88, 722-743.

Godwin-Austin, (1869): Notes from Assaloo, North Cachar, on the Great Earthquake of 10 January 1869 Proc. Asiatic Soc. Bengal, 15 March 1869, 91-99.

Hough, S.E., S. Martin, R. Bilham and G. AtKinson (2002): The January 26 2001, Bhuj India earthquake: Observed and predicted Ground Motions, Seismol. Soc. Am., 92 (6), 2061-2079.

IYENGAR, R.N. (1994): Earthquake History of South India, The Hindu, 23 January.

IYENGAR, R.N. and D. SHARMA (1998) Earthquake history of India in medieval times, Rep. Central Build. Res. Inst., Roorkee, pp. 124

JACKSON, D. (2002): The great western-Himalayan earthquake of 1505: a rupture of the central Himalayan gap?, in Tibet, Past and Present, edited by H. BLEZER (Brill's Tibetan Studies Library I, Leiden), 147-159.

KHAN, K. (1874): Muntakhab-ul Lubab, M.H., Bibl. India Series, Calcutta.

KHATTRI, K.N. (1987): Great earthquakes, seismicity gaps and potential for earthquake disaster along the $\mathrm{Hi}-$ malaya plate boundary, Tectonophysics, 138, 79-92.

KhatTRI, K.N and A.K. TYAGi (1983): Seismicity patterns in the Himalayan plate boundary and identification of areas of high seismic potential, Tectonophysics, 96, 281-297.

Lyell, C. (1830): Principles of Geology (John Murray, London).

MALlET, R. (1853): Catalogue of recorded earthquakes from 1606 B.C. to 1850 , Brit. Ass. Rep., 1853, 1-176; $1854,118-213 ; 1855,2-326$.

MidDLEMISS, C.S. (1910): The Kangra Earthquake of 4 April 1905, Mem. Geol. Soc. India, Geol. Surv. India, 38, pp. 409

OldHAM, R.D. (1884): Note on the earthquake of 31 December 1881, Rec. Geol. Surv. India, 17 (2), 47-53.

OLDHAM, R.D. (1885): Geology of the Andaman Islands with references to the Nicobars, Rec. Geol. Surv. India, 18 (3), 135-145.

OldHAM, R.D. (1898). A note on the Allah Bund in the north west of the Runn of Cuch. Mem. Geol. Soc. India, Geol. Surv. India, 28, 27-30.

Oldham, R.D. (1899): Report on the Great Earthquake of 12 June 1897, Mem. Geol. Soc. India, Geol. Surv. India, 29, pp. 379.

OldHAM, R.D. (1928): The Cutch (Kacch) earthquake of 16. June 1819 with a revision of the great earthquake of 12. June 1897, Mem. Geol. Soc. India, Geol. Surv. India, 46, 71-147.

OldHAM, T. (1883): A catalogue of Indian earthquakes, Mem. Geol. Surv. India, Geol. Surv. India, 19, 163-215.

OrTIZ, M. and R. BILHAM (2003): Source area and rupture parameters of the 31 December $1881 \mathrm{Mw}=7.9 \mathrm{Car}$ Nicobar earthquake estimated from Tsunamis recorded in the Bay of Bengal, J. Geophys. Res., 108 (B4), doi: 2002JB001941RR2003.

PANDEY, M.R. and M. NiCOLAS (1989): The Aftershocks sequence of the Indian-Nepalese earthquake of Augus 20, 1988, Report 2 March 1989 (HMG Ministry of Industry, Nepal, Dept. of Mines and Geology, Lainchaur, Kathmandu)

Paul, J., R. Burgmann, V.K. Gaur, R. Bilham, K.M. Lar-
SON, M.B. Ananda, S. Jade, M. Mukal, T.S. AnupaMA, G. SATYAL and D. Kumar (2001): The motion and active deformation of India, Geophys. Res. Lett., 28 (4), 647-651.

PoDDAR, M.C. (1953): A short note on the Assam earthquake of Aug. 15, 1950, in A Compilation of Papers on the Assam Earthquake of August 15, 1950, edited by M.B.R. Rao, Publ. No. 1 (Central Board of Geophysics, Gov. of India), 38-42.

RAJENDRAN, C.P. (2000): Using geological data for earthquake studies: a perspective from peninsula India, Curr. Sci., 79 (9), 1251-1258.

RAJENDRAN, C.P and K. RAJENDRAN (2001): Characteristics of deformation and past seismicity associated with the 1819 Kutch earthquake, Northwestern India, Bull. Seismol. Soc. Am., 91 (3), 407-426.

RAJENDRAN, C P and K. RAJENDRAN (2002): Historical constraints on previous seismic activity and morphologic changes near the source zone of the 1819 Rann of Kachchh earthquake: further light on the penultimate event, Seismol. Res. Lett., 73 (4), 470-479.

RAJENDRAN, C.P., K. RAJENDRAN and B. JoHn (1996): The Killari (Latur), Central India, earthquake: an example of fault reactivation in the Precambrian crust, Geology, 24, 651-654

RAJENDRAN C.P, K. RAJENDRAN, K.H. Vora and A.S. GAUR (2003): The odds of a seismic source near Dwarka, NW Gujarat: An evaluation based on proxies, Curr. Sci., 84, 695-701.

RAO, B.R. and P.S. RAO (1984): Historical seismicity of Peninsular India, Bull. Seismol. Soc. Am., 74 (6), 25192533.

RAY, S. (1953): Isoseismals for the great Assam Earthquake of August 15 1950, in A Compilation of Papers on the Assam Earthquake of August 15, 1950, edited by M.B.R. RaO, Publ. No. 1 (Central Board of Geophysics, Gov. of India), 35-37.

SEEBER, L. and V. GoRnitz (1983): River profiles along the Himalayan arc as indicators of active tectonics, Tectonophysics, 92, 335-367.

Seeber, L., G. Ekstrom, S.K. Jain, C.V.R. Murthy, N. ChandaK and J.G. Ambruster (1996): The 1993 Killari earthquake in Central India: a new fault in Mesozoic basalt flows?, J. Geophys. Res., 101 (B4), 8543-8560.

SElla , G.F., T.H. DiXON and A. MAO (2002): REVEL: a model for recent plate velocities from space geodesy, $J$. Geophys. Res., 107, doi: 10.1029/2000JB000033.

SinHA, K.K. (1993): Isoseismal Studies, Bihar-Nepal Earthquake August 20 1988, Geol. Surv. India., Spec. Publ. 31, pp. 104.

SRI DEVI JADE and 12 OTHER AUTHORS (2003): Pre-seismic, coseismic and post seismic displacements associated with the Bhuj earthquake derived from recent and historic geodetic data, J. Ind. Inst Sci., 112 (3), 331-346.

SRIVASTAVA, N.N. and K. RAMACHANDRAM (1985): A new catalogue of earthquakes for Peninsular India during 1839-1900, Mausam, 36 (30), 351-358.

Sukhija, B.S., M.N. RaO, D.V. Reddy, P. Nagabshanam, S. Hussain, R.K. CHADHA and H.K. GuPTA (1999): Timing and return of major paleoseismic events in the Shillong Plateau, India, Tectonophysics, 308, 53-65.

STEIN, S., G. SELLA and E. A OKAL (2002): The January 26, 
2001 Bhuj earthquake and the diffuse boundary of the Indian plate, Amer. Geophys. Un. Geodyn. Monogr. 30, 243-254.

TANDON, A.N. (1953): The very great earthquake of August 15 1950, in A Compilation of Papers on the Assam Earthquake of August 15, 1950, edited by M.B.R. RAO, Pub. No. 1 (Central Board of Geophysics, Gov. of India), 80-89.

Thorn, W. (1818): Memoir of the War in India Conducted by General Lord Lake and Major General Sir Arthur Wellesley, Duke of Wellington (T. Egerton Military Library, Whitehall, London), 93-94.

Wang, Qi, Pei-Zhen Zhang, J.T. Freymueller, R. Bil- ham, K.M. LaRSON, XI'an LaI, X. YoU, Z. NiU, J. WU, Y. Li, J. LiU, Z. YANG and Q. CHEN (2001): Present day crustal deformation in China constrained by global positioning measurements, Science, 294, 574-577.

Wesnousky, S.G., S. Kumar, R. Mohindra and V.C. THAKUR (1999): Holocene slip rate of the Himalaya frontal thrust of India - Observations near Dehra Dun, Tectonophysics, 18, 967-976.

Wright, D. (1877): History of Nepal (reprint, Ranjan Gupta, Calcutta, 1966, pp. 271)

Yule, H. and A.C. BuRnell (1903): Hobson-Jobson: a Glossary of Colloquial Anglo-Indian Words (New Delhi, John Murray), pp. 1021 (reprint, 1995, 320-321). 